\title{
Scrutiny of MT-SOFC Stack Manifolding Design Using CFD
}

\author{
V. Lawlor* ${ }^{1,2}$, C. Hochenauer ${ }^{1}$, A. Mariani ${ }^{5}$, S. Griesser ${ }^{1}$, S. Kuehn ${ }^{4}$, K. Klein ${ }^{4}$, A. G. Olabi ${ }^{2}$, \\ S. Cordiner ${ }^{5}$, D. Meissner ${ }^{1,3}$ and G. Buchinger ${ }^{1}$ \\ ${ }^{I}$ Department of Eco-Energy, Upper Austrian University of Applied Science, A-4600 Wels, Austria \\ ${ }^{2}$ Department of Manufacturing and Mechanical Engineering Dublin City University, Dublin 9, Ireland \\ ${ }^{3}$ Tallinn Technical University, Ehitajate tee 5, Tallinn 19086, Estonia \\ ${ }^{4}$ eZelleron GmbH, Collenbuschstr. 22, 01324 Dresden, Germany \\ ${ }^{5}$ Dipartimento di Ingegneria Meccanica - Università di Roma Tor Vergata, Italy
}

\begin{abstract}
In this work we investigated the use of Computational Fluid Dynamics (CFD) in order to describe the behaviour of a single Micro Tubular Solid Oxide Fuel Cell (MT-SOFC) and a bundle thereof. It is the first step before building a rather necessarily complicated experimental apparatus in order to compare the predictions with experimental measurement. The first goal of this study was to test the suitability of commercially available CFD \& SOFC modelling software, with some modified features. The second goal was to predict the effects of various fuel and oxidant manifolding techniques regarding temperature, species and current density distributions. A result of this paper showed that CFD is a very useful tool, when a SOFC module is incorporated for MT-SOFC stack modelling. A second result showed that the oxidant flow regime was much more important than the fuel regime in order to manipulate a single MT-SOFC's temperature profile. The cases investigated had a radiation model included and the differences in temperature profiles, when radiation was included and neglected, especially for MT-SOFCs with view factors to the reactor housing, was shown to be important. The CFD predictions clearly showed the benefits and advantages associated with the different forms of fuel and oxidant manifoldings. A future experimental analysis is currently being designed.
\end{abstract}

Keywords: MT-SOFC, CFD, manifolding, gas flow, temperature, simulation.

\section{INTRODUCTION}

SOFCs are becoming ever more relevant as a means of converting fuels to electricity. The fact that they can be fuelled with hydrocarbon fuels, require no precious materials in their production and now with smaller versions, can be rapidly heated to operational temperature makes them an ever more viable alternative to traditional energy conversion systems. SOFCs produce excess heat that may thermally self sustain the stack, drive peripheral electricity generation devices or reformers or indeed, heat water. When a SOFC, or stack thereof, is combined with gas turbines, on the exhaust side, the overall system efficiency can be quite impressive [1-7]. This extra heat may also be provided to an external fuel reformer. The Micro Tubular Solid Oxide Fuel Cell (MT-SOFC) is a much smaller version of the standard planar and tubular SOFC systems. It is an evolution of the standard SOFC that has added resilience against thermal shocks, which allows a fast start-up and a high power per volume [8]. Also, with regard to manufacture, the smaller MT-SOFC is desirable as for example, Appelby [9] suggested that ceramic parts have thermo-mechanical problems and special

*Address correspondence to this author at the Department of Eco-Energy, Upper Austrian University of Applied Science, A-4600 Wels, Austria; Tel: +43-7242-72811-5507; E-mails: vlawlor@gmail.com,

Vincent.lawlor@fh-wels.at reliability aspects, which influence their manufacture rejection rate. Hence, ideally the ceramic SOFC should be physically much smaller than Phosphoric Acid Fuel Cells (PAFC) or Molton Carbonate Fuel Cells (MCFC). Finally SOFC electrodes and electrolytes are much cheaper than those in other fuel cell types, such as the Polymer Electrolyte Membrane fuel cell [10].

It would seem that the MT-SOFC has many beneficial characteristics that the larger SOFC types cannot adhere to, with specific reference to their high volumetric power density and thermal shock resistance. In 1995 Penner [11] mentioned, in a paper dealing with the commercialization of SOFCs, amongst many other improvements, that increasing tubular SOFCs power density was key to their marketplace potential. The MT-SOFC is not mentioned in this paper but its power density is much greater than the larger SOFC tube type. Lutsey et al. [12] have shown that small SOFCs are ideally suited for Auxiliary Power Unit (APU) use. For example, in long haul trucks when the SOFC is used during idling times. In their quantitative market potential and costeffectiveness study regarding a SOFC as a truck APU, they concluded that as SOFC technology approaches $\$ 800$ per net $\mathrm{kW}$ (in 2015), such a product would become cost effect for haulers with a two year payback time. It is not mentioned in this paper, but the MT-SOFC is the ideal candidate for such niche markets because it has a rapid start-up capability and 
high shock resistance. SOFCs have also been envisaged for Combined Heat and Power (CHP) in residential areas. There is no reason why MT-SOFCs could not replace the state of the art larger SOFC designs [6, 13, 14].

In the early 1990s the extrusion of thin YSZ ceramic tubes, with wall thicknesses of between 100 to $200 \mu \mathrm{m}$, which could be used as an SOFC electrolyte, by Prof. K. Kendall \& M. Kendall [15, 16], began the MT-SOFC research sector. Shortly after this achievement Kendall and his group [17] showed the first operational 1000 cell stack. Alston et al. [17] described the 1000 cell stack that was used to generate electricity from the MT-SOFCs and to heat water with the excess MT-SOFC heat generation. Their reactor was comprised of 40 modular stacks that were combined together to make a complete stack. They showed that hot air alone fed to the MT-SOFCs was sufficient in order to heat them up to their operating temperature and that these MTSOFCs could withstand $200^{\circ} \mathrm{C} \mathrm{m^{-1 }}$ temperature increases.

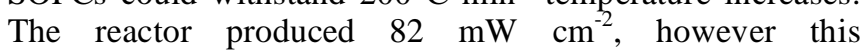
achievement positively proved that the MT-SOFC system was feasible. A substantial MT-SOFC literature range is available to the field, both with regard to modelling works and experimental work. For a detailed analysis of modelling and experimental activities up to 2009 the reader is referred to [18-20].

A suggestion by Lawlor et al., [18] was that there is no single paper regarding MT-SOFCs that explicitly outlines to the field the pros and cons of different fuel and oxidant manifoldings. Most groups publishing work in the sector usually use anode supported MT-SOFCs, where the electrolyte and cathode layers are dip coated or deposited onto a substrate [8, 21-29]. A few groups have published work on cathode supported MT-SOFCs [26, 30]. The majority of groups tend to use single inlet - single outlet fuel flow conditions (separated fuel inlet/outlet) see Fig. (1), where the fuel flows one-way through the MT-SOFC. However, as was discussed by Lawlor et al., [18] and indeed had been performed by $[21,31,32]$ there is an alternative method in order to supply the fuel where a counter-flow condition inside the MT-SOFC exists (combined fuel inlet/outlet), see Fig. (1).

Lee et al., [32] noticed, using the combined fuel inlet/outlet, a $30 \%$ increase in power density. They blocked their MT-SOFC end using a metallic brazing cap. This group suggested that the benefits of such a design should include improved fuel utilisation. This is because: a reduced hydrogen channel volume, i.e. the anode hollow, will exist; incoming fuel preheating, by the exhausted fuel; possible reduction in ohmic losses caused by the current collection, via this capillary pipe and finally the reduction in stack volume, a

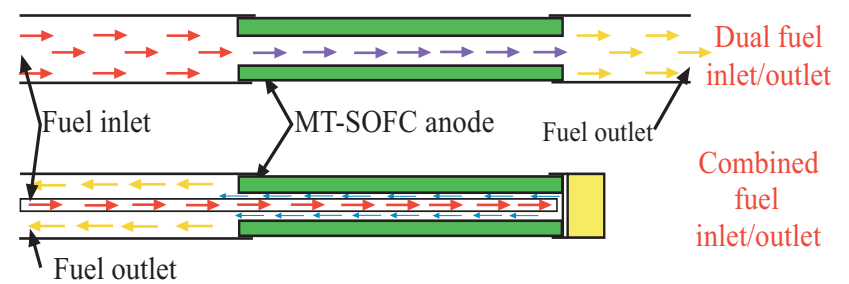

Fig. (1). Illustration showing the dual fuel inlet/outlet (top) and combined fuel inlet/outlet (bottom) methods. consequence of reduced manifolding inlets and outlets. Their MT-SOFC external diamater was $10 \mathrm{~mm}$, thus the interior diameter was probably about $5 \mathrm{~mm}$. Sarkar et al., [33] have also investigated MT-SOFCs having a similar manifolding method, whereby the MT-SOFC was made using Electrophoretic Deposition (EPD) techniques. An interesting feature of their MT-SOFCs is that the end of the cell, or end tip, is also ceramic. The advantage of such a design could be that if the MT-SOFC end is also active, then the MT-SOFC active area is increased. Furthermore the end seal reliability may be better than that of, for example Lee et al., [32].

The MT-SOFCs modelled in our study had a $2.7 \mathrm{~mm}$ external diameter and an internal diameter of $0.5 \mathrm{~mm}$. The fuel counter-flow manifolding system was first attempted by the group at the upper Austria University of Applied Sciences in 2009 (un-published work) with the conclusion that while such manifolding and current collection systems can certainly be made, the use of the small pipes needed to inlet/remove fuel from the cell induces system related parasitic pressure losses.

The characteristics of a combined inlet/outlet manifolding system have not been addressed, with specific comparison in the literature, especially regarding smaller MTSOFCs. Smaller MT-SOFCs have been shown to be more desirable with regard to hydrogen concentration and temperature [34], thermal shock resistance [8] and power density $[19,35]$ than larger cells. A goal of this paper was to use a commercially available CFD modelling package with electrochemical models in order to explore the attributes of the various manifolding techniques, discussed above, for a MTSOFCs with a diameter under $3 \mathrm{~mm}$. For further information on CFD modelling of SOFCs the reader is pointed to [3638].

\section{THEORY BEHIND THE NUMERICAL CALCULA- TION}

A commercially available CFD modelling program [39] with an additional electrochemical module [40] was used in order to simulate the different manifold designs discussed in this study. The fuel cell module predicts the electrochemical performance of the SOFC and is built upon the following equations and principles. Because the local Nernst potential depends upon the fuel and oxidant composition at the three phase boundary locations, a SOFC's current density distribution and the transport behaviour are quite locally dependent. Additionally the activation and limit losses coupled with the electrolyte are a function of the current density. In the electrochemical module, chosen for this study [40], either side of the electrolyte was partitioned by local potential difference. The Nernst potential, the ohmic losses within in the electrolyte and the activation losses associated at the electrode/electrolyte interfaces provided the terms required in order to calculate this potential difference.

Equation 1 represents the previously mentioned calculation as a potential difference between the anode and the cathode [40].

$$
\delta E=N-i \Omega_{\text {ele. }} t_{\text {ele }}-\eta_{\text {act }}(i)
$$


Where " $\mathrm{i}$ " is the local current density, " $\Omega_{\text {ele }}$ "is the the Ohmic resistance of the electrolyte at a given temperature "telec", "N" is the Nernst potential, " $\delta \mathrm{E} "$ is the difference in potential and " $\boldsymbol{\eta}_{\text {act" }}$ are the activation losses at a given local current density $i$.

The CFD-SOFC module chosen [40] assumed an ideal case whereby there was uniform contact between the electrodes and highly conductive current connectors. Electrochemical reactions that contain elements for the electric field, mass species and energy transport, Fluid flow, heat transfer and mass transfer in the channels and porous electrodes are accounted for by including a term in the electrochemical model. The electric field, mass species and energy transport, fluid flow, heat transfer and mass transfer in the manifolds and porous electrodes are considered, since electrochemical reaction terms for these phenomena are included in the electrochemical model. Furthermore since the electrochemical performance within the cell is coupled to the flow and temperature, the following standard conservation laws, Equations (2-4), are used in the model [40]:

$$
\begin{aligned}
& \text { Mass } \\
& \frac{d \rho_{i}}{d t}+\nabla \cdot \rho_{i} v=S_{m, i}
\end{aligned}
$$

Momentum

$$
\frac{d}{d t}(\rho v)+\nabla \cdot \rho v^{2}=\nabla \rho+\nabla \cdot \mu \nabla v+\rho g
$$

\section{Energy}

$$
\frac{d \rho_{e}}{d t}+\nabla \cdot\left[v\left(\rho_{e} e+p\right)\right]=\nabla Q+S_{h}
$$

Where $\rho i$ is the species density, $v$ is the fluid velocity, $t$ is the time, $\mathrm{p}$ is the pressure, $\mu$ is the viscosity, $\mathrm{g}$ is the gravitational constant, $\mathrm{Q}$ is the heat flux vector, and e is the total energy per unit mass, $\mathrm{S}_{\mathrm{m}, \mathrm{i}}$ is the rate of species $i$ production due to the electrochemical reactions, and $S_{h}$ is the volumetric heat source [41, 42].

In all solid MT-SOFC components, the electric field solution, including electrode and electrolyte ohmic heating is accounted for by equation (5) [40].

$$
\phi_{\text {jump }}=\phi_{\text {ideal }}-\eta_{\text {ele }}-\eta_{\text {act }, a}-\eta_{\text {act }, c}
$$

Where $\eta_{e l e}$ is the ohmic over-potential of the electrolyte, $\eta_{a c t, c}$ is the cathode over-potential, $\eta_{a c t, a}$ is the anode over-potential and ${ }_{\phi_{\text {ideal }}}$ is the Nernst potential.

Three-dimensional electrical conduction is directly comparable to the calculation of heat transfer and the CFD software [39] uses this concept as a means to calculate the electric field. The conservation of charge is the basis for the calculation of the potential field throughout the electrically conducting regions of a model. This is expressed below in Equations (6-7) [40].

$\nabla \cdot i=0$ where

$$
i=-(\sigma \nabla \phi)
$$

" $\sigma$ " is the electrical conductivity, $\phi$ " is the electrical potential and "i" is the current density.

The red-ox reactions must be modelled at the electrodes, electrolyte and gas species interfaces. Sleiti [36] provided an excellent general break down of the CFD software fuel cell module operation. The activation over-potential at the anode $\left(\eta_{\text {act,a }}\right)$ and the cathode $\left(\eta_{\text {act,c }}\right)$ can be determined based on a version of the Butler-Volmer equation, Equation (8), and the rate of species production and reduction by electrochemical reaction is described by Equation (9):

$$
\begin{aligned}
& \eta_{\text {act }}=\frac{2 R T}{n F} \sinh ^{-1}\left(\frac{i}{2 i_{\text {oeff }}}\right) \\
& S(\mathrm{~g} \text { mole } / \mathrm{s})=\frac{a i}{n F}
\end{aligned}
$$

Where $S$ is the species source or sink, $a$ is the stoichiometric coefficient, $i$ is the current density, $n$ is the number of electrons per fuel mole, and $F$ is the Faraday constant. Using the local electrical current information, the SOFC model applies species fluxes to the electrode boundaries. Therefore, the reactions at the cathode and anode electrodes are considered in Equations (10-11) [41].

$$
S_{O_{2}^{--}}=-\frac{i}{2 F}
$$

and

$$
S_{\mathrm{H}_{2} \mathrm{O}}=\frac{i}{2 F}
$$

For more information regarding the solution procedure and equations the reader is pointed to documentation from the CFD code provider [40] or from excelent summaries by produced by Sleiti [36] or Christman and Jensen [41].

The predictability of this approach has been compared in the thesis of Lawlor [43] and publication [44] to experimental results, whereby another case Lawlor et al., [45], was used as the experimental setup. These results can be found in [44]. The results showed that these models under those conditions of [45] provided adequate accuracy regarding species, temperature and electrical performance of the MTSOFC under test. The same electrochemical and MT-SOFC properties were used in this study.

The MT-SOFC dimensions were: anode thickness $85 \times 10^{-5} \mathrm{~m}$; electrolyte thickness $1 \times 10^{-5} \mathrm{~m}$ and cathode thickness $5 \times 10^{-5} \mathrm{~m}$. The MT-SOFC modelled had a $2.7 \mathrm{~mm}$ external diameter and a $1 \mathrm{~mm}$ internal diameter. The MTSOFC active area was $1.86 \times 10^{-4} \mathrm{~m}^{2}$. In order simplify the model, it was decided that in the single MT-SOFC model and also peripheral MT-SOFCs in the multi-cell model, would have asymmetric conditions. Thus these MT-SOFCs were modelled in half (see Fig. 2 and Fig. 6). In the CFD software, the Discrete Ordinates (DO) model was utilised in order to model infra red radiation. This modelling approach solves the thermal radiation transfer equation for a finite 


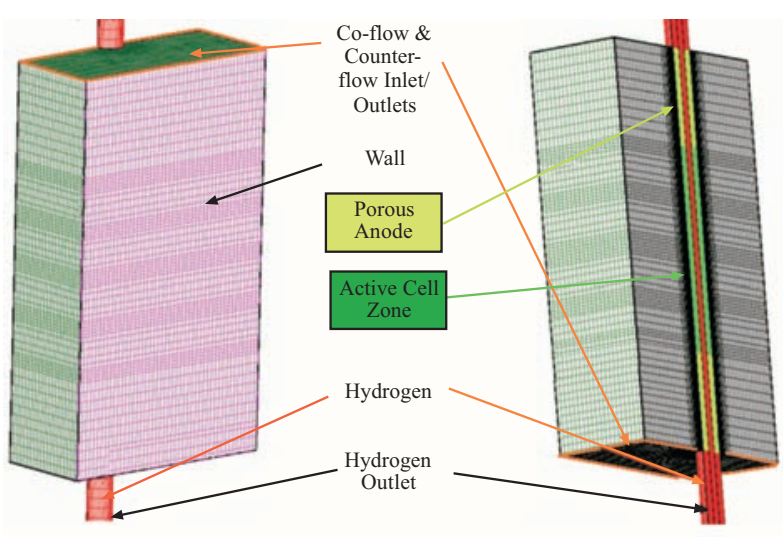

Fig. (2). Image of the boundary conditions with meshing for the single MT-SOFC simulations.

number of discrete solid angles. Every angle is coupled to a vector direction and the discretization must be chosen. For more information regarding the DO-model the reader is referred to [39]. It was chosen that radiation should be included in the models because of our experimental experiences in $[45,46]$. While the simulation results are not explicitly validated for performances within a bundle or at operational temperatures above $1018 \mathrm{~K}$, the MT-SOFC temperature profile, when similar experimental conditions to [46] were applied, matched very well. The DO-model was solved with every flow iteration and was discretised with $5 \mathrm{X} 5$ phi and $5 \mathrm{X} 5$ theta divisions. Note that the values for emissivity on the MT-SOFC wall were obtained from [46] and the emissivity's on the proposed testing apparatus housing were fitted. Table 1 shows the boundary conditions used in the single cell case.

For, momentum, body forces, species, the SOFC module and DO discretization the $2^{\text {nd }}$ order upwind discretization scheme was used. The standard discretization scheme was used for pressure. Discretization of the energy within the model was considered via a third order discretization "QUICK" approach. The Reynolds numbers, for the flows both inside and outside the MT-SOFC, can be described as laminar. This was deduced using a standard calculation and reference to a standard engineering moody diagram, for flow inside a pipe and literature available for flow around a cylinder in cross flow [47]. A detailed description of the modelling parameters, used in the CFD solving process can be seen in Table 2 .

\section{Table 1. Detailed Modeling Parameters}

\begin{tabular}{|c|c|c|}
\hline Modelling Parameters & Value & Units \\
\hline \hline Electrical Properties & & \\
\hline Anode conductivity & 333330 & $1 / \mathrm{ohm}$ \\
\hline Cathode Conductivity & 7937 & $1 / \mathrm{ohm}$ \\
\hline Nickel and silver conductivity & $1.50 \mathrm{E}+07$ & $1 / \mathrm{ohm}$ \\
\hline Silver touch cathode resistance & $1 \mathrm{E}-8$ & ohm-m ${ }^{2}$ \\
\hline Nickel touch anode resistance & $1 \mathrm{E}-7$ & ohm-m \\
\hline Anode & & \\
\hline
\end{tabular}

Table 1. Contd....

\begin{tabular}{|c|c|c|}
\hline Modelling Parameters & Value & Units \\
\hline Density & 3310 & $\mathrm{~kg} / \mathrm{m}^{3}$ \\
\hline $\mathrm{Cp}$ & 430 & $\mathrm{j} / \mathrm{kg}-\mathrm{K}$ \\
\hline Thermal conductivity & 1.86 & $\mathrm{w} / \mathrm{m}-\mathrm{K}$ \\
\hline Porosity & 0.3 & \\
\hline \multicolumn{3}{|l|}{ Cathode } \\
\hline Density & 3030 & $\mathrm{~kg} / \mathrm{m}^{3}$ \\
\hline $\mathrm{Cp}$ & 470 & $\mathrm{j} / \mathrm{kg}-\mathrm{K}$ \\
\hline Thermal conductivity & 2.16 & $\mathrm{w} / \mathrm{m}-\mathrm{K}$ \\
\hline Porosity & 0.3 & \\
\hline \multicolumn{3}{|l|}{ Current collectors } \\
\hline Density & 8900 & $\mathrm{~kg} / \mathrm{m}^{3}$ \\
\hline $\mathrm{Cp}$ & 446 & $\mathrm{j} / \mathrm{kg}-\mathrm{K}$ \\
\hline Thermal conductivity & 72 & $\mathrm{w} / \mathrm{m}-\mathrm{K}$ \\
\hline Porosity & 0.75 & \\
\hline \multicolumn{3}{|l|}{ Modelling Parameters } \\
\hline Mixture species & \multicolumn{2}{|c|}{$\mathrm{O}_{2} \mathrm{~N}_{2} \mathrm{H}_{2} \mathrm{O} \mathrm{H}$} \\
\hline Reaction & \multicolumn{2}{|c|}{ Finite-Rate } \\
\hline Mechanism & \multicolumn{2}{|c|}{ reaction-mechs } \\
\hline Density & \multicolumn{2}{|c|}{ Inc. Ideal gas } \\
\hline $\mathrm{CP}$ & \multicolumn{2}{|c|}{ mixing law } \\
\hline Thermal conductivity & \multicolumn{2}{|c|}{ ideal gas mixing law } \\
\hline Viscosity & \multicolumn{2}{|c|}{ ideal gas mixing law } \\
\hline Mass diffusivity & \multicolumn{2}{|c|}{ User-defined } \\
\hline Thermal diffusion coefficient & \multicolumn{2}{|c|}{ kinetic theory } \\
\hline UDS diffusivity & \multicolumn{2}{|c|}{ defined per uds } \\
\hline solver & \multicolumn{2}{|c|}{ pressure based } \\
\hline Formulation & \multicolumn{2}{|c|}{ implicit } \\
\hline Time & \multicolumn{2}{|c|}{ steady } \\
\hline Velocity formulation & \multicolumn{2}{|c|}{ absolute } \\
\hline Gradient option & \multicolumn{2}{|c|}{ green gauss cell based } \\
\hline porous formulation & \multicolumn{2}{|c|}{ superficial velocity } \\
\hline \multicolumn{3}{|l|}{ Species model } \\
\hline Model & \multicolumn{2}{|c|}{ Species transport } \\
\hline Reactions & \multicolumn{2}{|c|}{ volumetric } \\
\hline \multirow[t]{3}{*}{ Options } & \multicolumn{2}{|c|}{ diffusion energy source } \\
\hline & \multicolumn{2}{|c|}{ full multicomponent diffusion } \\
\hline & \multicolumn{2}{|c|}{ thermal diffusion } \\
\hline
\end{tabular}


Table 2. Characteristics of the Single Cell Modeling Boundary Conditions

\begin{tabular}{|l|l|}
\hline \multicolumn{1}{|c|}{ Boundary } & \multicolumn{1}{c|}{ Condition } \\
\hline \hline Oxidant inlet temperature & $983 \mathrm{~K}$ \\
\hline Oxidant inlet velocity & $0.04 \mathrm{~m} / \mathrm{s}$ \\
\hline Oxidant inlet per mass species & $23 \% \mathrm{O}_{2} 77 \% \mathrm{~N}_{2}$ \\
\hline Oxidant inlet emmisivity & 0.7 \\
\hline Walls emmisivitiy and flux & $0.7 \&$ (adeibatic) \\
\hline Fuel inlet mass flow & $6.4 \mathrm{E}-8 \mathrm{~kg} / \mathrm{s}$ (half cells) \\
\hline Fuel inlet temperature & $983 \mathrm{~K} \mathrm{\&} \mathrm{300} \mathrm{K} \mathrm{where} \mathrm{stated}$ \\
\hline Fuel inlet per mass species & $99 \% \mathrm{H}_{2} 1 \% \mathrm{H}_{2} \mathrm{O}$ \\
\hline Oxidant inlet/outlet emmisivity & 0.7 \\
\hline Cell emmisivity & 0.93 \\
\hline
\end{tabular}

The solution meshing interdependency was checked, in the cross flow single cell and bundle cases. This was done by adapting the grid using the hanging node method, which increasing the cell amount in the models by a factor of 8 from the original 138,390 for the bundle case and 146,000 for the single cell case. No major differences in the current density distributions or temperature profiles were noted, indicating no solution grid dependency. Furthermore, in both cases, all residuals settled below $1 \times 10^{-6}$ and monitoring of several key values, which showed little value fluctuation, indicated suitable convergence. For more information regarding MTSOFC meshing the reader is pointed to [44].

\section{CASE DESCRIPTION}

\subsection{Single MT-SOFC Simulation}

In the single MT-SOFC model only half the MT-SOFC and housing was modelled and symmetry conditions were applied to all wall and fluid regions crossing this zone, as seen in Fig. (2). Oxidant cross-flow (where the oxidant flow is perpendicular to the MT-SOFC), counter-flow (where the oxidant flow is parallel to the MT-SOFC and in the opposite direction regarding the fuel flow) and co-flow (where the oxidant flow is parallel to the MT-SOFC and in the same direction regarding the fuel flow) were all simulated. Furthermore two types of fuel inlet manifolding designs were also simulated and are discussed in more detail later.

\subsubsection{Separate Inlet/Outlet Fuel Manifold Technique}

Shown in Fig. (2) is the boundary conditions layout for the single cell model. The box surrounding the MT-SOFC is the housing and oxidant inlet and outlet zones. The co-flow and counter-flow regimes were realised by feeding the oxidant parallel to fuel flow. The co and counter flow inlets are explicitly shown in Fig. (2). The fuel flow in this paper, as a reference for the reader, was always inletted from "image" top to bottom. Thus the co- and counter-flow regimes will occur when the oxidant is fed from -top to bottom- co-flow exists and when fed from -bottom to top-, counter flow ex- ists. Cross flow occurs when the oxidant flow is fed perpendicularly to the MT-SOFC.

Fig. (3) outlines the MT-SOFC elements and where they appear in the model. In the CFD program that was used, the electrolyte was not drawn, but was instead defined as a 1dimensional zone, which is situated between the anode and cathode 3-dimensional zones. Please see reference [40] for more detail. As in the case of the anode supported MTSOFC, which had an electrolyte thickness of $10 \mu \mathrm{m}$, in this investigation, the effect of the electrolyte regarding heat production and resistance to ion flow was assumed sufficiently low. Thus it was decided accurate enough as a 1-dimensional zone. The current collection from the anode and cathode sides occurred, via the silver on the cathode (left image in Fig. 3) and nickel on the anode (right image in Fig. 3). The hydrogen flow path through the cell is shown in the center image of Fig. (3) (red path).

To give the reader and others interested in this sort of modeling an idea of how to mesh such geometries, for MTSOFCs, the meshing radially through the cell and radially through the oxidant boundary zone can be seen in Fig. (4).

\subsubsection{Combined Inlet/Outlet Fuel Manifold Technique}

Shown in Fig. (5) is a capillary tube that allows fuel counter flow inside the anode. The possible advantages of such a system have been discussed in the introduction section. The pink zone in Fig. (5) is a capillary pipe specially shaped to fit into the anode hollow. It has two purposes; firstly to allow fuel to be injected into the MTSOFC in a counter-flow manner, where the exhaust fuel should heat the incoming fuel and secondly to provide the anode electrical connection.

\subsection{Bundle of Cells Simulation}

It was chosen that in order to give the reader a more interesting read, the consequence of the different manifolding techniques on a larger system, incorporating a MT-SOFC bundle, should be considered. In Fig. (6), all three oxidant

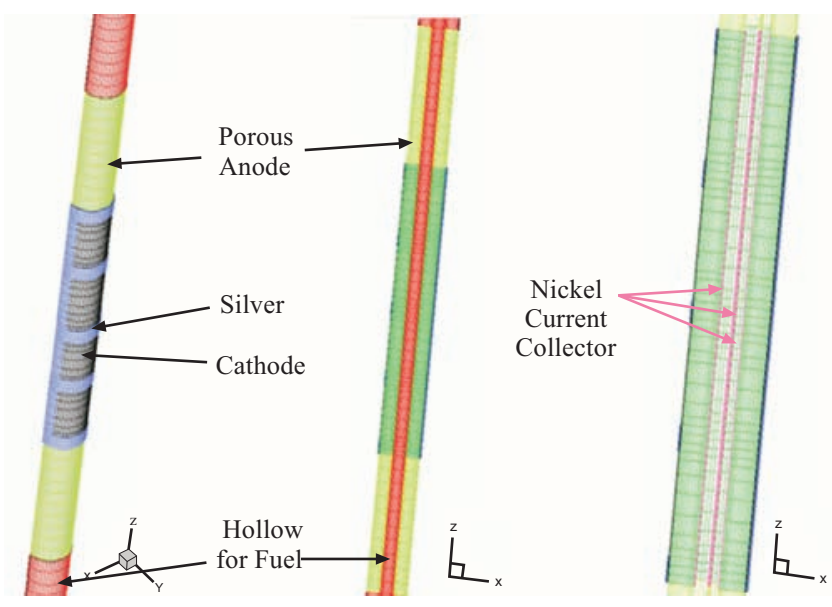

Fig. (3). Image of the different elements of the cell and fuel flow channels. (left) View outside the MT-SOFC where the cathode and silver current collectors are shown. (middle) View showing the hollow for fuel flow and porous regions. (right) A view showing the chosen nickel current collection at the anode. 


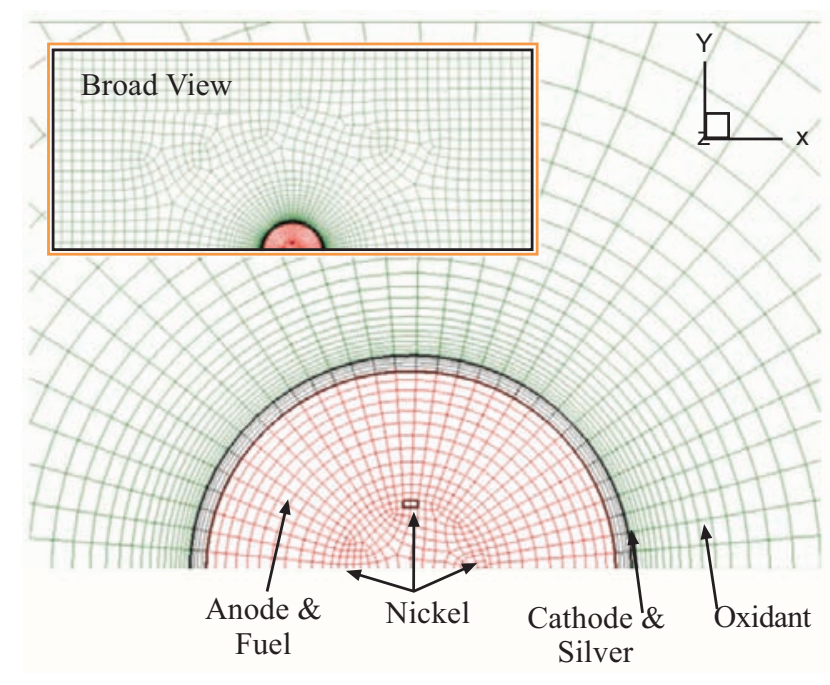

Fig. (4). Detailed view of the meshing around the cell with a picture insert of a broad view of the complete box holding the cell.

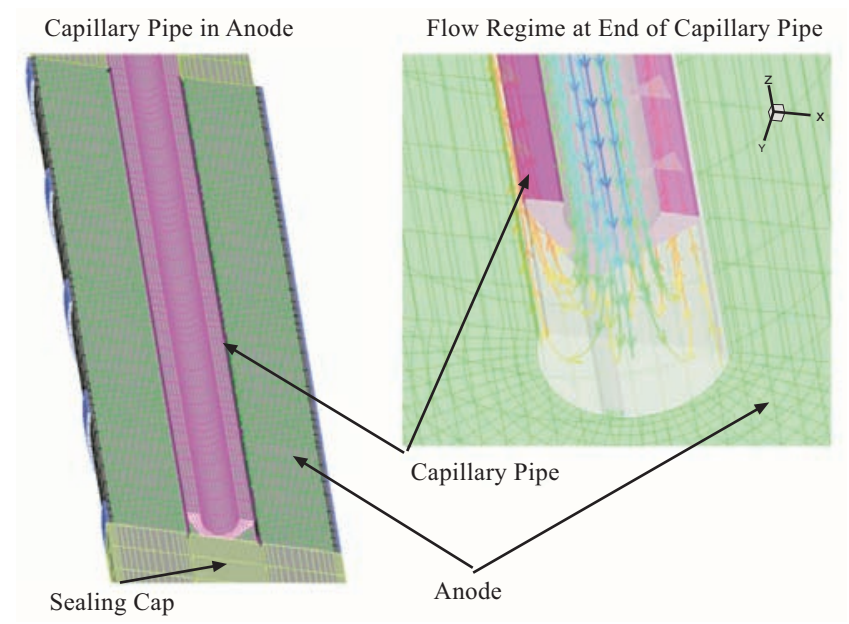

Fig. (5). (Left) Layout of the capillary tube inside the MT-SOFC with the grid. (Right) Illustration showing how the fuel leaves the capillary pipe and flows into the anode.

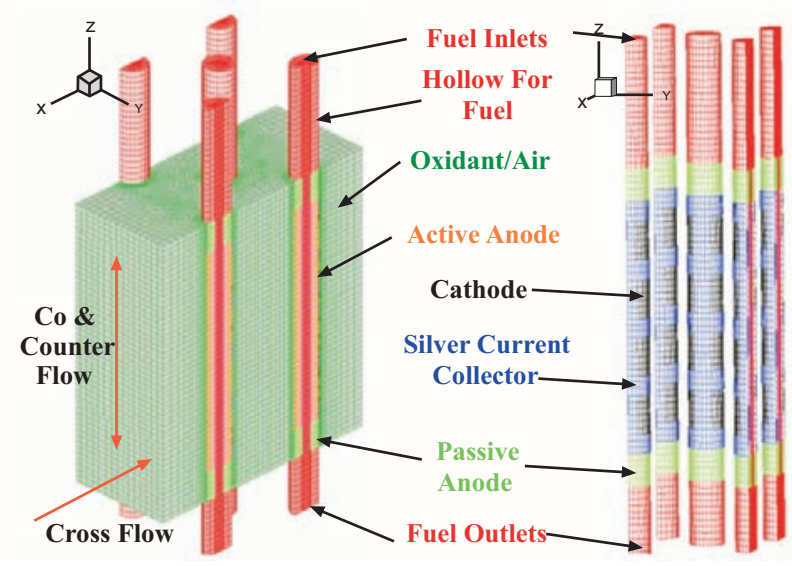

Fig. (6). Illustration showing the meshing and layout of the cells in the model and the boundary conditions.

flow regimes, which were applied to the singles MT-SOFCs, were also applied to a MT-SOFC bundle. The model con- sisted of one whole MT-SOFC and 4 halved MT-SOFCs, whereby the half MT-SOFCs and flow regions on the same plane had symmetry conditions. This can be regarded as a section in a stack, where the MT-SOFCs are arranged three MT-SOFCs deep. Table 3 shows the boundary condition characteristics for this setup.

\section{RESULTS}

\subsection{Single MT-SOFC Simulations}

\subsubsection{Separate Inlet/Outlet Fuel Manifold Technique}

Although a separate experimental analysis is also planned and needed in order to validate the following simulation results, these results still provided a reasonable prediction of the flow regimes, heat transfer characteristics and MT-SOFC performance for the different manifoldings studied. Experiments have been used in order to study identical MT-SOFCs inside a high temperature testing apparatus [45, 46]. The numerical and experimental results for current density, and temperature matched, qualitatively, very well. Further comparisons are not provided as the case modelled, while similar, was not identical to the experimental setup. The only difference between the prior mentioned case and the single MT-SOFC modelled in this account is that the MT-SOFC housing had 6 walls rather than 5, please refer to [44-46]. I.e. in the experimental case one wall was removed to provide a means of thermographic measurement, while in this simulated case this missing wall was included. Nonetheless the qualitative analysis of the current density and temperature profiles for both cases concur.

In this study, three different oxidant flow regimes were simulated using two different fuel manifolding techniques. Note that $\mathrm{A}, \mathrm{B} \& \mathrm{C}$ relate to positions at the bottom, middle and top of the MT-SOFCs, shown in Fig. (7) left (crossflow). Table 4 shows a comparison of co-, counter- and cross-flow including temperature and current density in the single MT-SOFC model. The oxidant manifolding in the coand counter-flow conditions resulted in a $0.03 \mathrm{~A} / \mathrm{cm}^{2}$ increased current density when compared to the cross flow case.

Table 3. Characteristics of the Boundary Conditions in the Multi Cell Model

\begin{tabular}{|l|l|}
\hline \multicolumn{1}{|c|}{ Boundary } & \multicolumn{1}{c|}{ Condition } \\
\hline \hline Oxidant inlet temperature & $983 \mathrm{~K}$ \\
\hline Oxidant inlet velocity & $0.12 \mathrm{~m} / \mathrm{s}$ \\
\hline Oxidant inlet per mass species & $23 \% \mathrm{O}_{2} 77 \% \mathrm{~N}_{2}$ \\
\hline Oxidant inlet emmisivity & 0.7 \\
\hline Walls emmisivitiy and flux & $0.7 \&($ adeibatic) \\
\hline Fuel inlet mass flow & $6.4 \mathrm{e}-8 \mathrm{~kg} / \mathrm{s}$ (half cells) \\
\hline Fuel inlet temperature & $983 \mathrm{~K}$ \\
\hline Fuel inlet per mass species & $99 \% \mathrm{H}_{2} 1 \% \mathrm{H}_{2} \mathrm{O}$ \\
\hline Oxidant inlet/outlet emmisivity & 0.7 \\
\hline General cell emmisivity & 0.93 \\
\hline
\end{tabular}


Table 4. Single Cell Simulation Results of 3 Oxidant Manifoldings with a Separate Inlet/Outlet Fuel Manifold Please see Fig. (7) for Locations of $\mathrm{A}, \mathrm{B} \& \mathrm{C}$

\begin{tabular}{|c|c|c|c|}
\hline Regime & Avg. A/cm ${ }^{2}$ & Avg. Temp [K] & A, B \& C- Temp. [K] \\
\hline \hline Cross-flow & 1.42 & 1029 & $1026,1032 \& 1026$ \\
\hline Counter-flow & 1.45 & 1045 & $1041,1048 \& 1034$ \\
\hline Co-flow & 1.44 & 1045 & $1038,1048 \& 1042$ \\
\hline
\end{tabular}

This was most likely caused by the $16^{\circ} \mathrm{C}$ average temperature difference of the MT-SOFC active regions. When comparing Table 4 (separate fuel inlet/outlet case) and Table 5 (combined fuel inlet/outlet case) no stark differences in average temperature or current densities were noticeable. This implies that cross flow, regardless of the fuel manifolding, seemed to have the highest heat removal quality. Because it was considered that the combined inlet/outlet fuel manifolding system had beneficial heat transfer attributes over the separate inlet/outlet fuel manifolding system, a simulation was made where the inlet fuel temperatures were set to $300 \mathrm{~K}$ rather than $981 \mathrm{~K}$.

The result showed that the benefit of the cross-flow case was just $2{ }^{\circ} \mathrm{C}$ as seen in Table 6. A calculation of the heat removal properties, considering the mass flow rate of the fuel and oxidant, their specific heat capacities vindicated this result. Thus indicating, that the oxidant was the dominant heat removal gas. Also, both methods produced almost exactly the same average current density, meaning no advantage was obtained from the combined fuel inlet/outlet manifolding in the fuel channel. Nevertheless, Lee et al., [32] noticed a $30 \%$ increase in power density during their study. However their MT-SOFC had much larger internal fuel channel diameter and this may be the reason why the power densities findings did not concur. With regard to the temperature profiles across the cell, the largest temperature difference, $7-10^{\circ} \mathrm{C}$, between the MT-SOFC ends was found to occur in the oxidant counter flow method, in both fuel manifolding cases.

\subsubsection{Combined Inlet/Outlet Fuel Manifold Technique}

Fig. (7) shows the separate fuel inlet/outlet case for all three oxidant manifolding cases. It can be seen how the oxidant flow affected the temperature profile and average MTSOFC temperature. In Fig. (8), a much clearer temperature
Cross-Flow

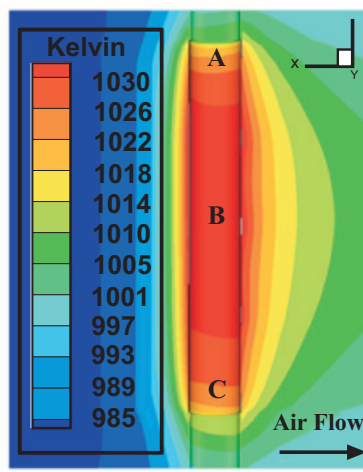

Counter-Flow

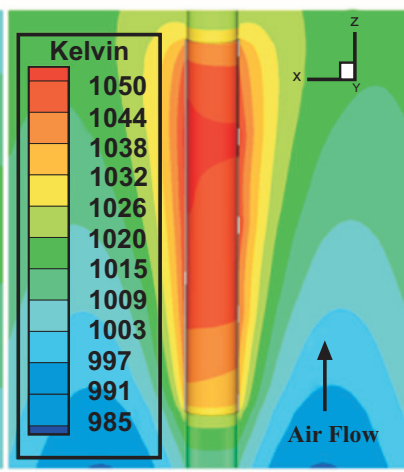

\section{Co-Flow}

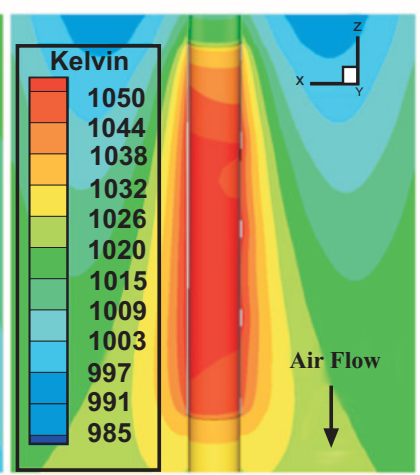

Fig. (7). Images for the 3 flow regimes showing a broad analysis of the temperature gradient across the cell.

Table 5. Single Cell Simulation Results of 3 Oxidant Manifoldings with a Combined Inlet/Outlet Fuel Manifold

\begin{tabular}{|c|c|c|c|}
\hline Regime & Avg. A/cm ${ }^{2}$ & Avg. Temp [K] & A, B \& C- Temp. [K] \\
\hline \hline Cross-flow & 1.42 & 1028 & 1024,10371029 \\
\hline Counter-flow & 1.44 & 1044 & $1032,1049,1042$ \\
\hline Co-flow & 1.43 & 1044 & 1038,10471032 \\
\hline
\end{tabular}

Table 6. Comparison Between Combined (C) and Separate (D) Inlet Manifolds on a MT-SOFC with a Fuel Inlet Temperature of $300 \mathrm{~K}$

\begin{tabular}{|c|c|c|}
\hline Regime & Avg. A/cm & Avg. Temp [K] \\
\hline \hline (C) Cross & 1.41 & 1020 \\
\hline (D) Cross & 1.41 & 1022 \\
\hline
\end{tabular}


profile, by virtue of a zoomed in scale, across electrolyte/cathode interface visualisation is shown. Cross-flow produced the most mirrored temperature profile across the MT-SOFC length. In this case at MT-SOFC ends, where sealing would most likely occur, the temperatures were the same at each end. This may have some advantages with regard to thermal expansion, but such a statement would require a Finite Element Method (FEM) analysis. The temperature variation across the MT-SOFCs in co- and counterflow cases was quite stark, see Fig. (8) and Table 5. Also, in the counter-flow case, the temperature across the MT-SOFC is smoother, especially on the fuel outlet (bottom) side.

Another important difference, between the three flow regimes, is the effect of oxygen distribution and concentration. Obviously, because of the similar current densities in all three cases, no distinguishable diffusion limitations from the oxidant side acted on the modelled MT-SOFC. Fig. (9) showed that the oxygen distribution was more evenly distributed, when the MT-SOFC was in cross-flow, compared to the co- and counter-flow cases. In the co-flow case, where the oxygen and fuel concentrations were depleting simultaneously per MT-SOFC unit length active area, the lowest amount of available oxygen was not as low as the counterflow case. At the MT-SOFC top in the counter-flow case, see Fig. (9), at the fuel inlet, the oxygen concentration was at its lowest level in all three cases. The reason for this was that before the bulk oxygen flow reached this position it had already been significantly depleted.

This could be a cause for concern, especially when MTSOFCs are in bundles. This is because the MT-SOFC part that was producing most current, at the hydrogen inlet, see Fig. (10), and thus could potentially experience oxygen diffusion limitations. In the co-flow case, this high oxygen de-
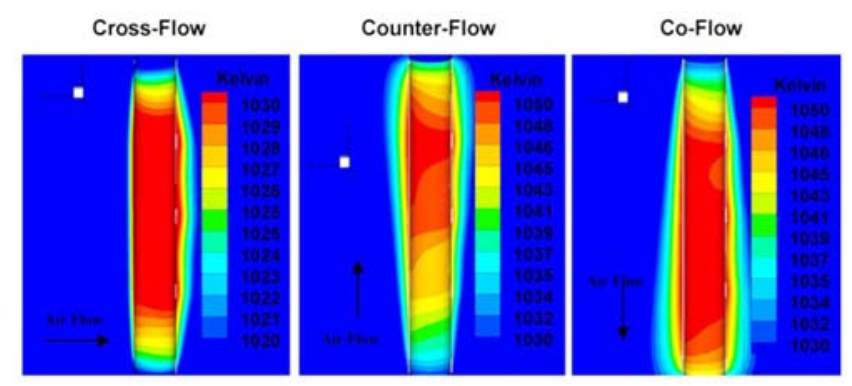

Fig. (8). Images for the 3 flow regimes showing an analysis of the oxygen mass gradient along the MT-SOFC.

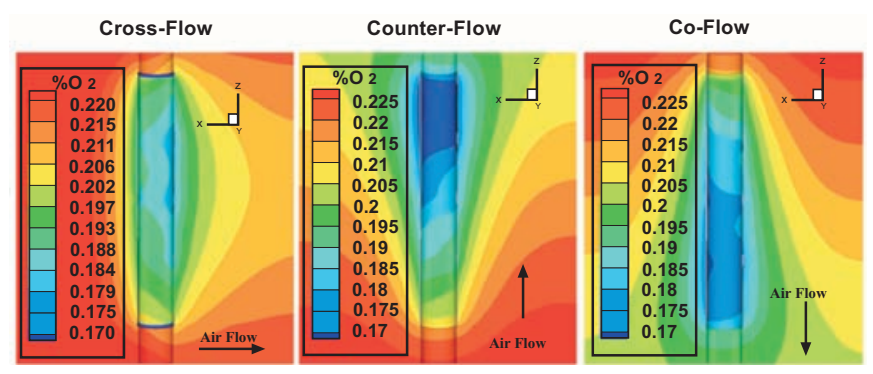

Fig. (9). Images for the 3 flow regimes showing current density on the cell wall (rainbow scale) and oxygen concentration (red-blue scale). Please compare the cathode current collection shown in Fig. (3). pletion did not occur, because the fuel and oxidant inlet are located at the same place and therefore concentrations of each component were high. This is not something that should cause concern in single MT-SOFC systems, but in MTSOFC bundles or MT-SOFCs that are very long or even MTSOFCs producing much more current than in the cases shown, this could be a parameter requiring optimisation. Fig. (10), illustrated that the temperature and oxygen profiles did not have much effect on the current density produced by each manifolding method. However, in the cross flow case, the peak current density was lower than in the co- and counter- flow cases. The most likely cause was that in the counter flow case, the highest temperatures were observed. Higher temperatures have a positive effect on MT-SOFC performance (i.e. lower electrolyte resistance) in the high current producing region.

It was surprising to observe that the combined inlet/outlet fuel manifolding method did not affect MT-SOFC performance, temperature- and current density- wise. This was probably due to the relatively low fuel mass flow rate in comparison to the oxidant. Fig. (11), shows a MT-SOFC core temperature contour plot with separate inlet/outlet and combined inlet/outlet fuel manifoldings as comparison. What this model did not allow for, because of the short fuel inlet manifold before the MT-SOFC, is that a longer inlet pipe or counter flow zone between the inlet and outlet fuel gas, in the combined inlet/outlet case, should certainly increase the system efficiency.

This could occur if the counter flow zone is sufficiently long enough to transfer enough heat between the hydrogen inlet and outlet pipes. Fig. (12) shows a comparison of the
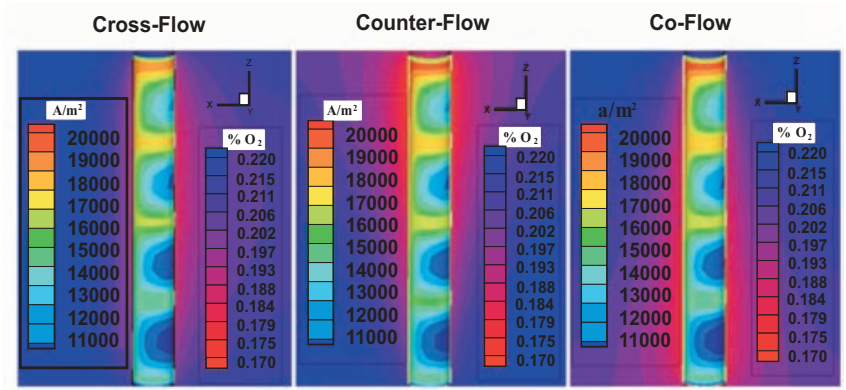

Fig. (10). Comparison of combined (left) and separate (right) fuel flow on a MT-SOFC with regard to cathode wall temperature.

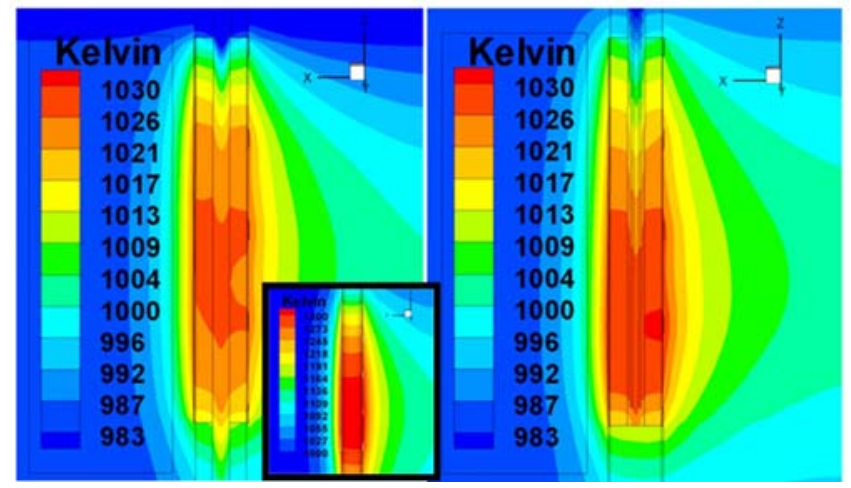

Fig. (11). Comparison of separate (left) and combined (right) fuel flow on a MT-SOFC with regard to static pressure inside the fuel channel 

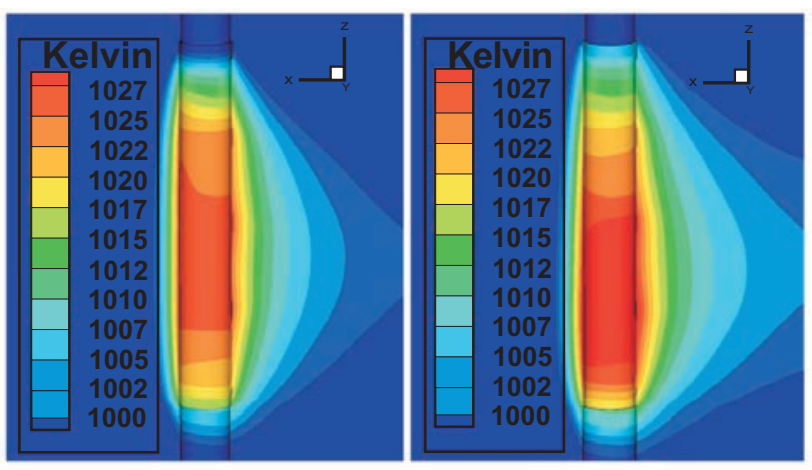

Fig. (12). Current density predictions for separate (left) and combined (right) fuel manifold techniques.

separate inlet/outlet and combined inlet/outlet fuel manifoldings and the temperature effect on the cathode wall. The insert on the separate inlet/outlet picture, Fig. (12), is a picture of the case when radiation was neglected. As has been shown in $[45,46]$ when MT-SOFCs were placed inside larger housings, radiation should be considered. As can be seen in this insert, the temperature difference was about 275 $\mathrm{K}$. This has very important implications for stack modelling. The emissivity and temperature on housing walls inside a stack have a substantial effect on the temperature profile inside the stack. Especially since such walls cannot be totally adiabatic, heat will be lost through radiation and conduction in the stack housing. Thus heat bridges should certainly be minimised. Furthermore radiation models are a necessity on the oxidant side of MT-SOFC models.

The parasitic pressure losses in the hydrogen capillary pipe and reduced volume fuel hollow in the anode are also a reason against such a system in small MT-SOFCs. As seen in Fig. (13), if capillary pipes, as small as those used in early experiments and in these simulations are used, then their lengths should be short in order to minimise pressure losses. However this opposes the proposed advantage of better heat transfer between the fuel inlet and exhaust, when the pipe lengths are "long" enough. Also bends on the capillary pipes should be avoided in order to reduce pressure losses and this can complicate a potentially novel stack manifolding solution.

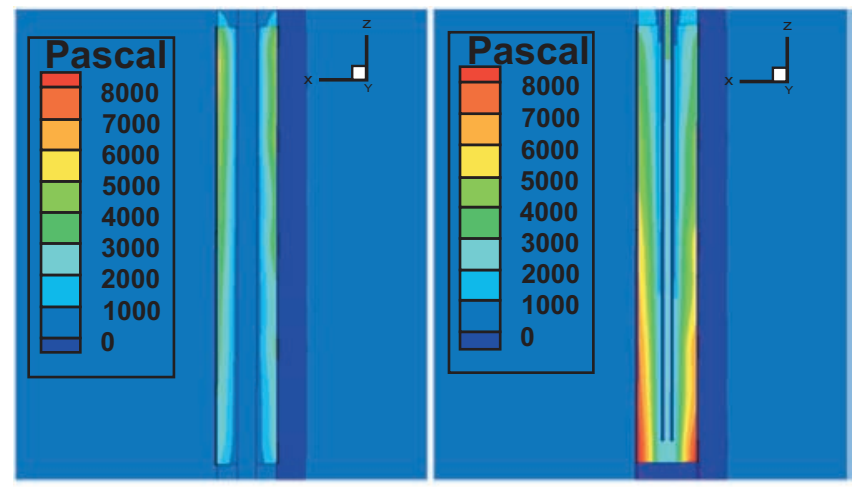

Fig. (13). Comparison of the temperature gradient through bundles in cross-, co- and counter-flow with an oxidant inlet temperature of $983 \mathrm{~K}$.
Fig. (14) shows the current density contours on the electrolyte cathode interface. A subtle difference in the current profiles was seen. At the inlet and under the silver current collectors, on the fuel inlet side of the combined fuel inlet/outlet case, the current density was a bit higher. This can be a result of the higher pressure in the MT-SOFC as seen in Fig. (13).

\subsection{Bundle of MT-SOFCs Simulations}

The single cell simulations have allowed a first glimpse regarding the effect of co-, cross- and counter-flow on MTSOFC performance. However of most interest to the fuel cell research sector is the effect within MT-SOFC bundles. Fig. (15) shows a comparison of the temperature contours through a MT-SOFC bundle in cross-, counter and co-flow with an oxidant inlet temperature of $987 \mathrm{~K}$ and velocity of $12 \mathrm{~cm} / \mathrm{s}$. Similar to the findings of the single MT-SOFC simulations, the cross flow case was better at removing heat from the bundle. Table 7 shows the average current densities and temperatures on the middle MT-SOFC in each bundle. The difference in temperatures between the co-counter- and cross flow cases was as much as $50{ }^{\circ} \mathrm{C}$. Furthermore Fig. (16) shows the temperatures on the MT-SOFC exterior.

It was interesting to observe when comparing Fig. (16) to Fig. (8) the consequence of the additional MT-SOFCs. In all three cases the effect of additional MT-SOFCs on the temperature profile of centre MT-SOFC was very observable. In the cross flow case, see Fig. (16), as much as a $15^{\circ} \mathrm{C}$ difference between the front and rear of the middle MT-SOFC was seen. In the single cell case this temperature gradient was not so stark. In the counter-flow case, for a single MT-SOFC, the temperature gradient across the cell ranged from $1048 \mathrm{~K}$ to $1038 \mathrm{~K}$, while on the middle cell in the bundle, this gradient ranged from $1098 \mathrm{~K}$ to $1016 \mathrm{~K}$, showing a slightly increased temperature gradient in the bundle case. A much more striking temperature gradient was clearly seen when comparing the co-flow single MT-SOFC and bundle case. In the single MT-SOFC case the temperature gradient ranged from $1038 \mathrm{~K}$ to $1048 \mathrm{~K}$ and on the middle MT-SOFC in the bundle, from $1075 \mathrm{~K}$ to $1122 \mathrm{~K}$.

This meant that co-flow of the fuel and oxidant may be a very undesirable flow regime because of induced thermal gradients across the MT-SOFC. A very interesting observation, also observed in Fig. (16) and Fig. (8) was the large

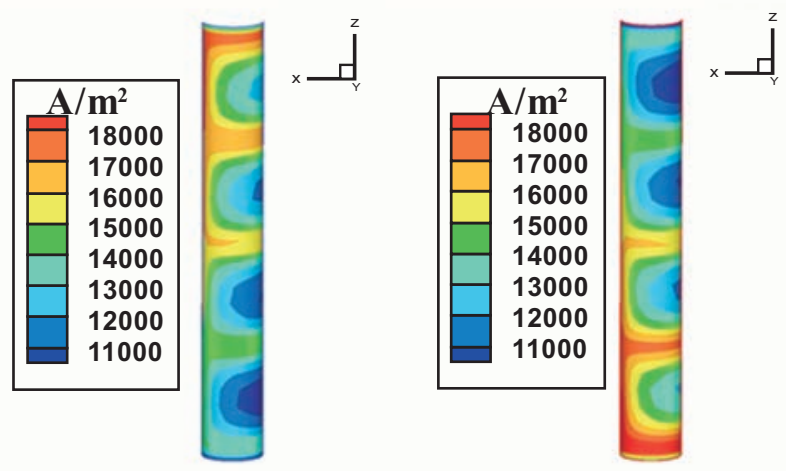

Fig. (14). Comparison of the temperature gradient on the cell walls in cross-, co- and counter-flow with an inlet temperature of $983 \mathrm{~K}$. 
Table 7. Middle Cell

\begin{tabular}{|c|c|c|c|}
\hline Regime & $\mathbf{A} / \mathbf{c m}^{2}$ & avg. temp. $[\mathbf{K}]$ & (A, B \& C) temp. [K] \\
\hline \hline Cross-flow & 1.40 & 1064 & $1051,1068 \& 1068$ \\
\hline Counter-flow & 1.39 & 1107 & $1101,1110 \& 1098$ \\
\hline Co-flow & 1.36 & 1105 & $1075,1111 \& 1122$ \\
\hline
\end{tabular}
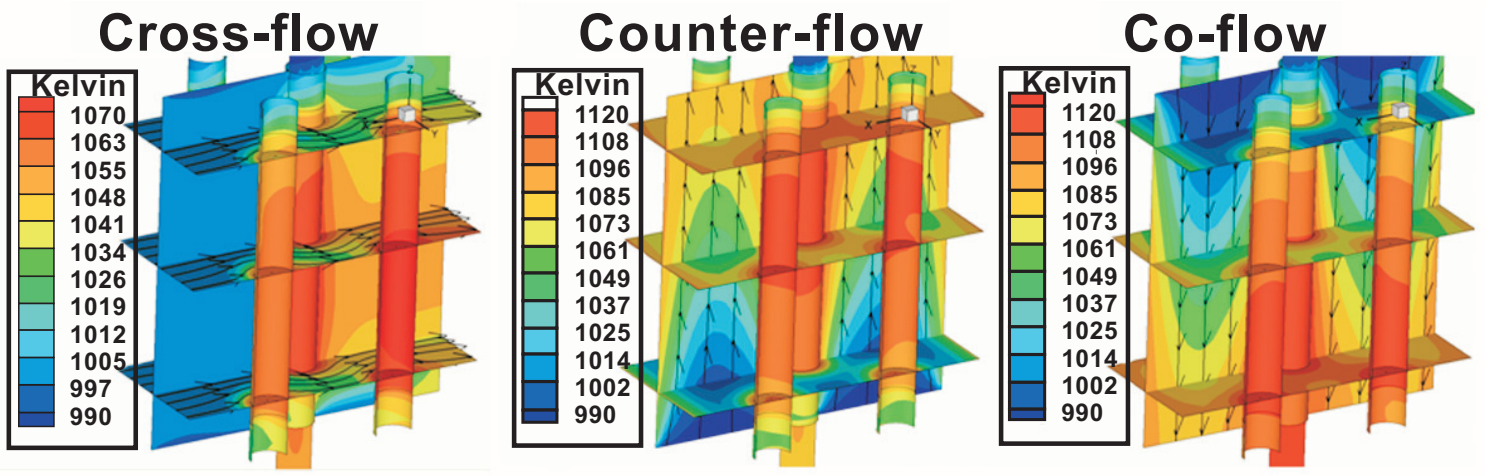

Fig. (15). Comparison of the mol oxygen fraction on the cell walls in cross-, co- and counter-flow with an inlet temperature of $983 \mathrm{~K}$.

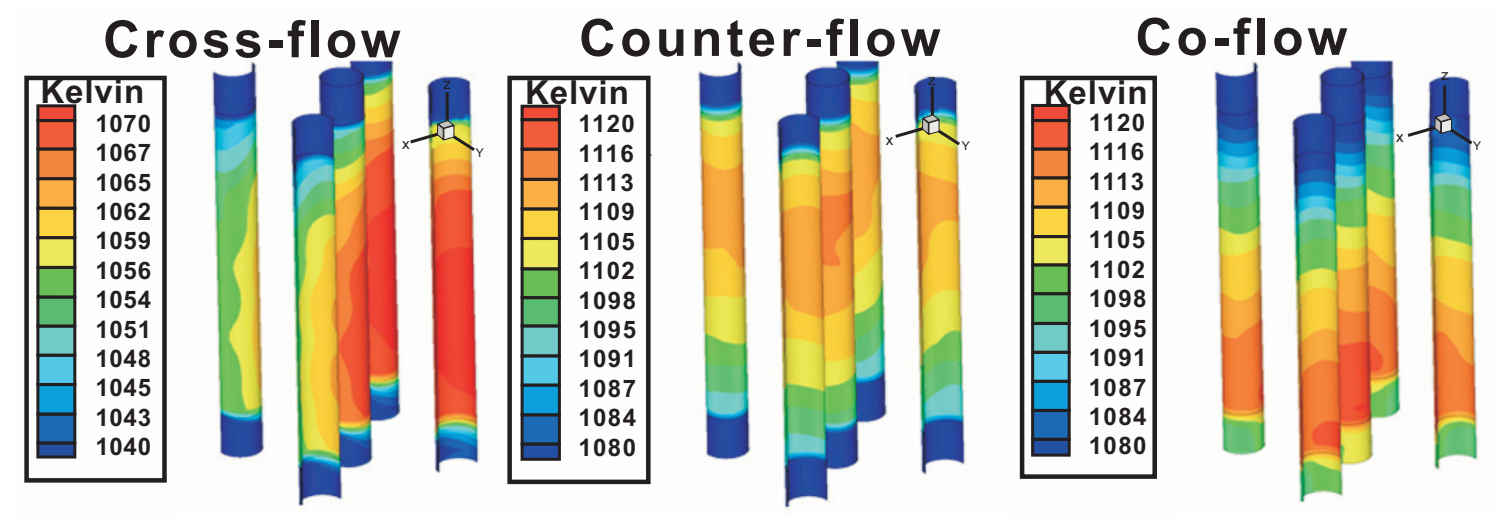

Fig. (16). Comparison of the current density on the cell walls in cross-, co- and counter-flow with an inlet temperature of $983 \mathrm{~K}$. Please compare the cathode current collection shown in Fig. (3).

temperature gradient between the active and passive MTSOFC parts. In the co-flow case this gradient, particularly on the fuel exhaust side, was much smoother than in the counter- and cross-flow cases. Such stark temperature contrasts were also observed in previous thermographic measurements and models [44, 45]. These simulations showed that the oxidant flow had the most pronounced effect on the temperature gradients across the MT-SOFC and can be regarded as the property that is most useful for heat removal and distribution thought a MT-SOFC bundle. This also points out that some smart optimisation of the distances between cells, which may not ideally be uniform, could be used in order to increase and decrease velocities within a stack, allowing regulation of the temperature and oxygen distribution.

Fig. (17) showed that the oxygen gradient was best minimised in the cross-flow case. It was interesting to note the oxygen gradient between the MT-SOFC front and rear, especially the comparison between this gradient at the fuel inlet and outlet ends for the MT-SOFC in cross-flow. The counter flow case was not optimal, with regard to oxygen concentrations at these flow rates, as can clearly be seen in Fig. (17). This was because the oxygen concentration was reduced as the air travels from the MT-SOFC fuel outlet side to the fuel inlet. At the fuel inlet side, refer Fig. (18), the current density is highest because of the higher fuel concentration.

\section{CONCLUSION}

To optimize a MT-SOFC stack in order to be: thermally self sustaining; to have temperature distributed uniformly through the stack and optimised oxygen distribution through the stack, a parameter study on: the effects of cell distances; oxidant flow rates and inlet temperature; effect of, for example, silver coatings on the cathode wall and indeed coatings on the stack housing on radiation losses, would need to be performed. The effect of the fuel flowing through the MTSOFCs on the overall MT-SOFC temperature or bundle 
thereof was much smaller than radiation and oxygen conduction/convection losses on the cathode side. While this initial study does not provide further information regarding optimisation of the above mentioned parameters, it does provide some predictions regarding the differences caused by providing oxidant to the cell in cross-, counter and co-flow on the temperature gradients. It was predicted from this study that cross flow provides the most homogeneous temperature and oxygen distributions through the three rows deep bundle. However, with regard to thermal self-sustainability the question may be proposed that the cross flow case removes heat too effectively, meaning that the inlet gas temperature would need to be higher.

Because the power produced by MT-SOFCs is highly temperature dependent, it was necessary to include an electrochemical model and it is the belief of our group that the best models will also include radiation in order to consider the effect of the stack walls and cell to cell temperature gradients, which can promote radiation losses. In this study an adiabatic wall assumption was made regarding the case study housing. This would not be the case in reality and should be considered in future studies.

To further improve the models developed, a current exchange density that varies with temperature may also be beneficial. Ni et al., [48] have shown that it can be very important to have temperature dependent current exchange densities. While we do not expect this current exchange density temperature dependency will have a drastic effect on our results, this feature will certainly be included into the next phase of our study. In the future this current exchange value can be fitted as a function of temperature also in our models. This paper showed that CFD is a very powerful tool that can be used in order to model and optimise the performance of MT-SOFC systems.

\section{ACKNOWLEDGEMENTS}

This project is being funded by the Austrian Science fund, Fonds zur Förderung der Wissenschaftlichen

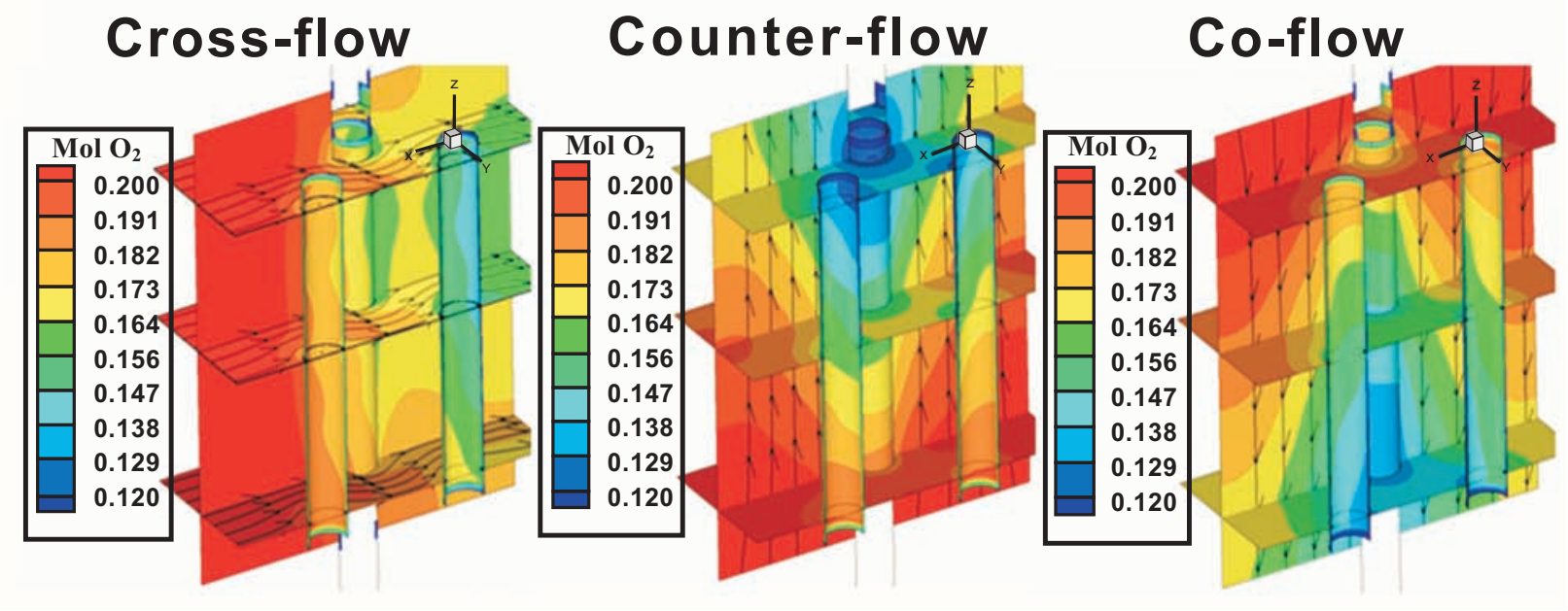

Fig. (17). Comparison of the temperature gradient through bundles in cross-, co- and counter-flow with an inlet temperature of $983 \mathrm{~K}$.

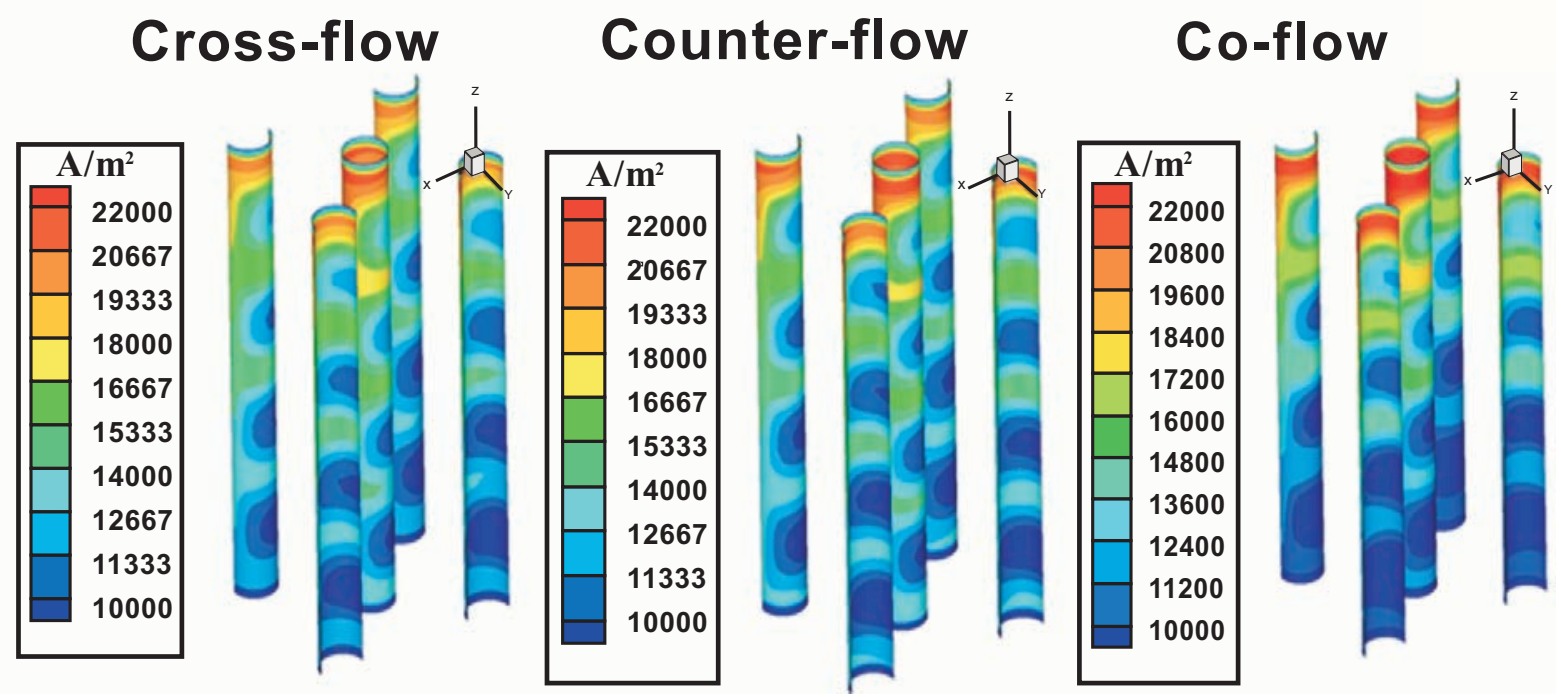

Fig. (18). Comparison of the temperature gradient on the cell walls in cross-, co- and counter-flow with an inlet temperature of $983 \mathrm{~K}$. 
Forschung (FWF), under the project title HIT-SIM (project number L611-N14) which is gratefully acknowledged.

\section{CONFLICT OF INTEREST}

None declared.

\section{REFERENCES}

[1] Calise, F.; Dentice d'Accadia, M.; Palombo, A.; Vanoli, L. Simulation and exergy analysis of a hybrid solid oxide fuel cell (SOFC)gas turbine system. Energy, 2006, 31(15), 3278-3299.

[2] Cocco, D.; Tola, V. Externally reformed solid oxide fuel cellmicro-gas turbine (SOFC-MGT) hybrid systems fueled by methanol and di-methyl-ether (DME). Energy, 2009, 34(12), 2124-2130.

[3] Kandepu, R.; Imsland, L.; Foss, B.A.; Stiller, C.; Thorud, B.; Bolland, O. Modeling and control of a SOFC-GT-based autonomous power system. Energy, 2007, 32(4), 406-417.

[4] Calise, F.; Dentice d' Accadia, M.; Vanoli, L.; von Spakovsky, M.R. Full load synthesis/design optimization of a hybrid SOFC-GT power plant. Energy, 2007, 32(4), 446-458.

[5] Komatsu, Y.; Kimijima, S.; Szmyd, J.S. Performance analysis for the part-load operation of a solid oxide fuel cell-micro gas turbine hybrid system. Energy, 35(2), 982-988.

[6] Burer, M.; Tanaka, K.; Favrat, D.; Yamada, K. Multi-criteria optimization of a district cogeneration plant integrating a solid oxide fuel cell-gas turbine combined cycle, heat pumps and chillers. Energy, 2003, 28(6), 497-518

[7] Santin, M.; Traverso, A.; Magistri, L.; Massardo, A. Thermoeconomic analysis of SOFC-GT hybrid systems fed by liquid fuels. Energy, 2010, 35(2), 1077-1083.

[8] Bujalski, W.; Dikwal, C.M.; Kendall, K. Cycling of three solid oxide fuel cell types. J. Power Sources, 2007, 171(1), 96-100.

[9] Appleby, A.J. Fuel cell technology: Status and future prospects. Energy, 1996, 21(7-8), 521-653.

[10] Gieleten, D.; Simbolotti, G. Prospects for hydrogen and fuel cells. (International energy agency, 2005).

[11] Penner, S.S.; Appleby, A.J.; Baker, B.S.; Bates, J.L.; Buss, L.B.; Dollard, W.J.; Fartis, P.J.; Gillis, E.A.; Gunsher, J.A.; Khandkar, A.; Krumpelt, M.; O'Sullivan, J.B.; Runte, G.; Savinell, R.F.; Selman, J.R.; Shores, D.A.; Tarman, P. Commercialization of fuel cells. Energy, 1995, 20(5), 331-470.

[12] Lutsey, N.; Brodrick, C.J.; Lipman, T. Analysis of potential fuel consumption and emissions reductions from fuel cell auxiliary power units (APUs) in long-haul trucks. Energy, 2007, 32(12), 2428-2438.

[13] Wakui, T.; Yokoyama, R.; Shimizu, K.I. Suitable operational strategy for power interchange operation using multiple residential SOFC (solid oxide fuel cell) cogeneration systems. Energy, 2010, 35(2), 740-750.

[14] Ghosh, S.; De, S. Energy analysis of a cogeneration plant using coal gasification and solid oxide fuel cell. Energy, 2006, 31(2-3), 345-363.

[15] Kendall, K. Development of microtubular solid oxide fuel cell. Proceedings of the International Forum on Fine Ceramics, pp. 143-148. Japan Fine Ceramics Center, Nagoya, 1992.

[16] Kendall, M. A novel SOFC design. Final year report. Middlesex University, 1993.

[17] Alston, T.; Kendall, K.; Palin, M.; Prica, M.; Windibank, P. A. 1000-cell SOFC reactor for domestic cogeneration. J. Power Sources, 1998, 71(1-2), 271-274.

[18] Lawlor, V.; Griesser, S.; Buchinger, G.; Olabi, A.G.; Cordiner, S.; Meissner, D. Review of the micro-tubular solid oxide fuel cell: Part I. Stack design issues and research activities. J. Power Sources, 2009, 193(2), 387-399.

[19] Kendall, K. Progress in microtubular solid oxide fuel cells. Int. J. Appl. Ceramic Technol., 2010, 7(1), 1-9.

[20] Kendall, K. Progress in solid oxide fuel cell materials. Int. Mater. Rev., 2005, 50(5), 257-264.

[21] Soderberg, J.N.; Sun, L.; Sarkar, P.; Birss, V.I. Oxygen reduction at LSM--YSZ cathodes deposited on anode-supported microtubular solid oxide fuel cells. J. Electrochem. Soc., 2009, 156(6), B721B728.
[22] Buchinger, G.; Kraut, J.; Raab, T.; Griesser, S.; Lawlor, V.; Haiber, J.; Hiesgen, R.; Sitte, W.; Meissner, D. Operating Micro-Tubular SOFCs Containing Nickel Based Anodes with Blends of Methane and Hydrogen. International Conference on Clean Electrical Power, 2007. ICCEP '07., pp. 450 - 455, Capri.

[23] Buchinger, G.; Hinterreiter, P.; Raab, T.; Griesser, S.; Lawlor, V.; Klein, K.; Kuehn, S.; Sitte, W.; Meissner, D. Stability of Micro Tubular SOFCs Operated with Synthetic Wood Gases and Wood Gas Components. Inter. Confer. Clean Electrical Power, 2007. ICCEP '07. , pp. 444 - 449.

[24] Calise, F.; Restucccia, G.; Sammes, N. Experimental analysis of micro-tubular solid oxide fuel cell fed by hydrogen. J. Power Sources, 2009, 195(4), 1163-1170.

[25] Nakajima, H.; Konomi, T.; Kitahara, T. Thermal analysis of a microtubular solid oxide fuel cell using electrochemical impedance spectroscopy. ECS Trans., 2009, 25(2), 359-368.

[26] Yamaguchi, T.; Shimizu, S.; Suzuki, T.; Fujishiro, Y.; Awano, M. Fabrication and characterization of high performance cathode supported small-scale SOFC for intermediate temperature operation. Electrochem. Commun., 2008, 10(9), 1381-1383.

[27] Campana, R.; Merino, R.I.; Larrea, A.; Villarreal, I.; Orera, V.M. Fabrication, electrochemical characterization and thermal cycling of anode supported microtubular solid oxide fuel cells. J. Power Sources, 2009, 192(1), 120-125.

[28] Galloway, K.V.; Sammes, N.M. Performance Degradation of Microtubular SOFCs Operating in the Intermediate-Temperature Range. J. Electrochem. Soc., 2009, 156(4), B526-B531.

[29] Dikwal, C.M.; Bujalski, W.; Kendall, K. The effect of temperature gradients on thermal cycling and isothermal ageing of microtubular solid oxide fuel cells. J. Power Sources, 2009, 193(1), 241248.

[30] Luebbe, H.; Rossen, J.; Diethelm, S.; Herle, J.V.; Hofmann, H.; Bowen, P.; Snijkers, F.; Betz, T. Fabrication and characterisation of cathode support-tubes for micro-tubular SOFC application. ECS Trans., 2009, 25(2), 2597-2606.

[31] Lee, S.B.; Lim, T.H.; Song, R.H.; Shin, D.R.; Dong, S.K. Development of anode supported micro-tubular SOFC stack for APU application. ECS Transactions - 10th International Symposium on Solid Oxide Fuel Cells, SOFC-, 2007, pp. 187-191.

[32] Lee, S.-B.; Lim, T.-H.; Song, R.-H.; Shin, D.-R.; Dong, S.-K. Development of a $700 \mathrm{~W}$ anode-supported micro-tubular SOFC stack for APU applications. Int. J. Hydrogen Energy, 2008, 33(9), 23302336.

[33] Sarkar, P.; Yamarte, L.; Johanson, L. Tubular micro-solid oxide fuel cell for remote power applications. ECS Trans., 2007, 7(1), 603-608.

[34] Serincan, M.F.; Smirnova, A.; Sammes, N.M. Modeling and analysis of a micro-tubular solid oxide fuel cell operating at intermediate temperatures. 10th International Symposium on Solid Oxide Fuel Cells, SOFC-X, J. Electrochem. Soc., 2007, pp. 1955-1965.

[35] Kendall, K. Progress in solid oxide fuel cell materials. Inter. Mater. Rev., 2005, 50, 257-264.

[36] Sleiti, A.K. Performance of tubular solid oxide fuel cell at reduced temperature and cathode porosity. J. Power Sources, 2010, 195(17), 5719-5725.

[37] Cordiner, S.; Mariani, A.; Mulone, V. CFD-based design of microtubular solid oxide fuel cells. J. Heat Transfer, 2010, 132(6), 062801-062815.

[38] Sciacovelli, A.; Verda, V. Entropy generation analysis in a monolithic-type solid oxide fuel cell (SOFC). Energy, 2009, 34(7), 850865.

[39] Fluent_inc. Fluent 6.3 User's Guide. 2006

[40] Fluent_Inc. [Online] Chapter 3 SOFC Model Theory. 2006.

[41] Christman, K.L.; Jensen, M.K. Solid oxide fuel cell performance with cross-flow roughness. J. Fuel Cell Sci. Technol., 2011, 8(2), 024501-024505.

[42] Prinkey, M. T.; Gemmen, R. S.; Rogers, W. A. Application of a new CFD analysis tool for SOFC technology. Proceedings of ASME IMECE, 2001, 369(4), pp. 291-300.

[43] Lawlor, V. Study to Characterise the performence of MT-SOFCs by the invention of an avant garde experimental apparatus and computational modelling. Department of Mechanical and Manufacturing Engineering (Dublin City University, Dublin, 2010.

[44] Lawlor, V.; Hochenauer, C.; Griesser, S.; Zauner, G.; Buchinger, G.; Meissner, D.; Olabi, A.G.; Klein, K.; Kuehn, S.; Cordiner, S.; Mariani, A. The use of a high temperature wind tunnel for MT- 
SOFC testing---part II: use of computational fluid dynamics software in order to study previous measurements. J. Fuel Cell Sci. Technol., 2011, 8(6), 061019.

[45] Lawlor, V.; Zauner, G.; Hochenauer, C.; Mariani, A.; Griesser, S.; Carton, J.G.; Klein, K.; Kuehn, S.; Olabi, A.G.; Cordiner, S.; Meissner, D.; Buchinger, G. The use of a high temperature wind tunnel for MT-SOFC testing---part I: detailed experimental temperature measurement of an MT-SOFC using an avant-garde high temperature wind tunnel and various measurement techniques. $J$. Fuel Cell Sci. Technol., 2010, 7(6), 061016-061017.

[46] Lawlor, V.; Zauner, G.; Mariani, A.; Hochenauer, C.; Griesser, S.; Carton, J.; Kuehn, S.; Klein, K.; Meissner, D.; Olabi, A.G.;
Cordiner, S.; Buchinger, G. A study to investigate methods to measure the temprature of a MT-SOFC in a high temperature wind tunnel. Third European Fuel Cell Technology and Applications Conference - Piero Lunghi Conference, ASME, Rome Italy, 2009, pp. 76-77.

[47] Coutanceau, M.; Defaye, J.-R. Circular cylinder wake configurations: a flow visualization survey. Appl. Mech. Rev., 1991, 44(6), 255-305.

[48] Ni, M.; Leung, M.K.H.; Leung, D.Y.C. Parametric study of solid oxide fuel cell performance. Energy Conversion Manag., 2007, 48(5), 1525-1535.

Received: July 23, 2011

(C) Lawlor et al.; Licensee Bentham Open.

This is an open access article licensed under the terms of the Creative Commons Attribution Non-Commercial License (http://creativecommons.org/licenses/by-nc/3.0/) which permits unrestricted, non-commercial use, distribution and reproduction in any medium, provided the work is properly cited. 